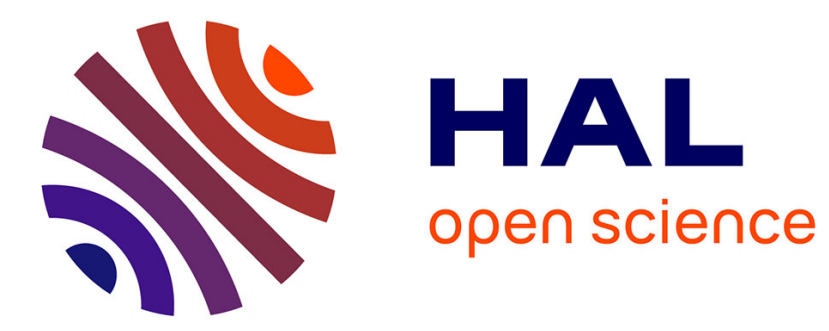

\title{
Rainfall Anomaly Patterns and Wind Field Signals over West Africa in August (1958-1989)
}

Bernard Fontaine, Serge Janicot, Vincent Moron

\section{To cite this version:}

Bernard Fontaine, Serge Janicot, Vincent Moron. Rainfall Anomaly Patterns and Wind Field Signals over West Africa in August (1958-1989). Journal of Climate, 1995, 8 (6), pp.1503-1510. 10.1175/15200442(1995)0082.0.CO;2 . hal-02894871

\section{HAL Id: hal-02894871 \\ https://hal.science/hal-02894871}

Submitted on 4 Feb 2021

HAL is a multi-disciplinary open access archive for the deposit and dissemination of scientific research documents, whether they are published or not. The documents may come from teaching and research institutions in France or abroad, or from public or private research centers.
L'archive ouverte pluridisciplinaire HAL, est destinée au dépôt et à la diffusion de documents scientifiques de niveau recherche, publiés ou non, émanant des établissements d'enseignement et de recherche français ou étrangers, des laboratoires publics ou privés. 


\title{
Rainfall Anomaly Patterns and Wind Field Signals over West Africa in August (1958-1989)
}

\author{
BERNARD FONTAINE \\ CNRS, Centre de Recherche de Climatologie and Laboratoire de Météorologie Dynamique, Dijon, France
}

SERGE JANiCOT

Météo-France, Laboratoire de Météorologie Dynamique du CNRS, Palaiseau, France

VINCENT MORON

Université de Bourgogne, Centre de Recherche de Climatologie, Dijon, France

(Manuscript received 31 December 1992, in final form 28 October 1994)

\begin{abstract}
Relationships between monthly West African rainfall anomaly patterns and monthly tropospheric wind changes are investigated for the 32 months of August (1958-1989) at an interannual time step. Regarding the Sahelian belt alone, results show that wet (dry) months are significantly linked to an increase (decrease) in both upper easterlies and lower southwesterlies, along with weaker (stronger) than usual midtropospheric easterlies south and under the main axis of the African Easterly Jet (AEJ). However, the most interesting signals are obtained with consideration of the West African rainfall anomaly patterns. Large droughts over Sahelian and Guinean areas are significantly associated with a less southward extension of upper easterlies and a decrease of the upper-meridional diffluence in the Hadley circulation. Contrasted rainfall anomaly patterns exhibiting both Sahelian droughts and Guinean floods are mainly linked to easterly anomalies in the equatorial stratosphere and enhanced easterlies south and under the AEJ, associated with a reduction of westerlies in the monsoon flow and midtropospheric southerly anomalies north of $15^{\circ} \mathrm{N}$. The opposite-contrasted rainfall patterns (Sahelian floods and Guinean droughts) are characterized by a southward extension of upper easterlies, a decrease of the easterlies extending south of the AEJ, an increase of wind components in the monsoon flow, and an increased confluence of the meridional components in the midtroposphere above $5^{\circ} \mathrm{N}$. Two indexes taking into account the vertical $(200 \mathrm{hPa} / 850 \mathrm{hPa})$ and the $850 \mathrm{hPa}$ latitudinal $\left(10^{\circ} \mathrm{N} / 20^{\circ} \mathrm{N}\right)$ relationships in the zonal wind component discriminate the two contrasted rainfall anomaly patterns. A third index, using the meridional components in high levels for documenting diffluence variability in the Hadley circulation, characterizes largescale West African droughts.
\end{abstract}

\section{Introduction}

West African rainfall monsoon circulation, mainly resulting from sea-land contrasts between $20^{\circ} \mathrm{W}$ and $20^{\circ} \mathrm{E}$, consists of three main wind axes: the southwesterly monsoon flow in the lower levels, the African Easterly Jet (AEJ) toward 600-700 hPa, and the Tropical Easterly Jet (TEJ) toward $150 \mathrm{hPa}$. Basically the low-level monsoon transports water vapor from the Atlantic Ocean (Hastenrath and Lamb 1977; Lamb 1983 ) and from evaporation-transpiration processes over the continent (Monteny 1985; Cadet and Nnoli 1987). The AEJ is a moderate jet stream baroclinically and barotropically unstable, which reflects south-north thermal gradients near the surface between hot Saharan

Corresponding author address: Dr. Serge Janicot, Laboratoire de Météorologie Dynamique, Ecole Polytechique, Route Départementale 36, 91128 Palaiseau Cedex, France. air masses and cooler Guinean and Atlantic ones. The TEJ, nearly twice as strong, has a larger spatial scale. It is first linked to the meridional thermal gradient, which settles in July-August between the Tibetan highlands and the Indian Ocean during the southwest Asiatic monsoon circulation (Koteswaram 1958). Second, despite dissipative processes that reduce its intensity over the Horn of Africa, it persists over the West African monsoon area where latent heat release transfers available potential energy into kinetic energy. West African rainfall amounts are mainly produced by disturbances such as easterly waves and squall lines (Rennick 1976; Reed et al. 1977; Riehl 1979; Song and Franck 1983) and possess a significant intraseasonal and interannual variability. This is particularly true over the Sahelian belt, which experiences its rainy season in the northern summer.

Sahelian droughts have already been associated with some wind anomalies: an enhancement of AEJ, a de- 
crease of TEJ (Kidson 1977; Newell and Kidson 1984), and a weaker south Hadley-type cell linked to a decrease of the monsoon flow (Lamb 1983; Newell and Kidson 1984; Folland et al. 1986). More recently, Fontaine and Janicot (1992) showed that the statistical coherence of the Hadley cells and of the east-west cell circulation at the monthly timescale vanishes during a dry period: an enhanced vertical shear due to a stronger AEJ weakens the statistical connection between the monsoon flux convergence and the air flux divergence associated with the TEJ.

However, it is now recognized that West African rainfall anomaly fields are organized into large-scale patterns (Nicholson 1981, 1986; Janowiak 1988; Janicot 1992a; Nicholson and Palao 1993). This suggests that the Sahelian rainfall variability is more a result of larger climatic fluctuations occurring in the boreal summer over the whole of West Africa than a single feature of regional extent. In other words, a given rainfall anomaly (droughts or floods) over the Sahel does not express a similar rainfall anomaly field over West Africa and may be associated with different wind field arrangements.

This paper deals with this topic. Therefore, the present investigation will take into account the available rainfall information not only over the Sahelian belt but over the whole of West Africa. Moreover, it will concentrate on the month of August to capture the strongest seasonal signals in the West African circulation (monsoon flow, AEJ, and TEJ) and in the rainfall patterns (peak of the Sahelian rainy season and of the Guinean little dry season ). August contributes also to a significant part of the variability, which affects seasonal and annual rainfall over these regions (Dennett et al. 1985; Moron 1994). A recent analyzed atmospheric dataset (1958-1989) will be used to provide an updated insight since the results of Newell and Kidson (1984), as well as those of Fontaine and Janicot (1992), were respectively based on 14 and 19 nonadjacent years.

\section{Data and methods}

The upper-air dataset is obtained from the GFDL Atmospheric Circulation Tape Library (NOAA). It consists of monthly means of atmospheric parameters objectively analyzed on a $73 \times 73$ global grid $\left(2.5^{\circ}\right.$ latitude, $5^{\circ}$ longitude) on 11 pressure levels (1000, 950, $900,850,700,500,400,300,200,100$, and $50 \mathrm{hPa}$ ) from May 1958 to December 1989. Basic information comes from global rawinsonde data (Oort 1978, 1983; Oort and Liu 1993). Differences in the analysis scheme and data reduction procedure exist between the period May 1958 to April 1963 and the remaining one. However, the five months of August 1958-1962 have been considered because they refer to the end of the wet period in the Sahel. The data density differs depending on geographical domains. The West African radio- sounding network mainly documents the $4^{\circ}-6^{\circ} \mathrm{N}$ latitudinal belt, the Sudano-Sahelian zone, and some Saharan locations. The Sahelo-Guinean domain and the equatorial Atlantic near the $0^{\circ}$ meridian are rather well documented and are considered as a highly reliable analyzed area (Oort 1983, p. 74). However, the quality of the 1000 and $50 \mathrm{hPa}$ data is poorer than in the 950 $100 \mathrm{hPa}$ layer.

Rainfall anomaly fields have been computed using an original subset of 110 selected West African stations for the period 1933-1990 taking into account their spatial distribution, their quality, and their availability (Moron 1992, 1994). No variation in station density exists from 1933 to 1990 as recommended by Katz and Glantz (1986), and factor analyses confirm the existence of coherent regions (Janicot 1992a; Nicholson and Palao 1993). Two "regional" indexes have been defined-a Central Sahelian Index (CSI) and a Guinean Index (GI) - by averaging the normalized departures of representative stations taking into account the spatial coverage and their statistical coherence (Moron 1992, 1994).

Relationships between August wind components and their connections with CSI are first investigated with use of linear correlation coefficients. Four basic rainfall patterns are then pointed out: two of them concern in phase variations over the central Sahel and the Guinean region; the two others concern out of phase variations (i.e., Sahelian droughts associated with Guinean floods and vice versa). The two in phase rainfall patterns will be referenced hereafter as "-_" (large droughts) and "++" (large floods) anomaly patterns, where the first sign concerns the Sahelian region and the second one the Guinean area. The two contrasted ones will be referenced as "-+" ("+-") anomaly patterns when negative (positive) anomalies extend over the central Sahel and positive (negative) anomalies occur over the Guinean region. Compositing techniques will be used and tested with Student's t-test.

Tests of significance take into account the temporal autocorrelation in the series to better estimate the accurate level of significance (Der Megreditchian 1979; Thiebaux and Zwiers 1984) and the real or equivalent number of independent series. This is estimated through Monte Carlo simulations following the method described by Livezey and Chen (1983) and by crosscorrelation matrixes according to Der Megreditchian (1979). The two methods give similar results. The statistical levels of significance are then computed by applying the binomial law (Sneyers 1975; Fontaine and Janicot 1992).

\section{Results}

\section{a. Rainfall time series in August}

Figure 1 enables comparison of the time series of CSI and GI during the period 1933-1989 and the more recent period 1958-1989. CSI is clearly more persistent 


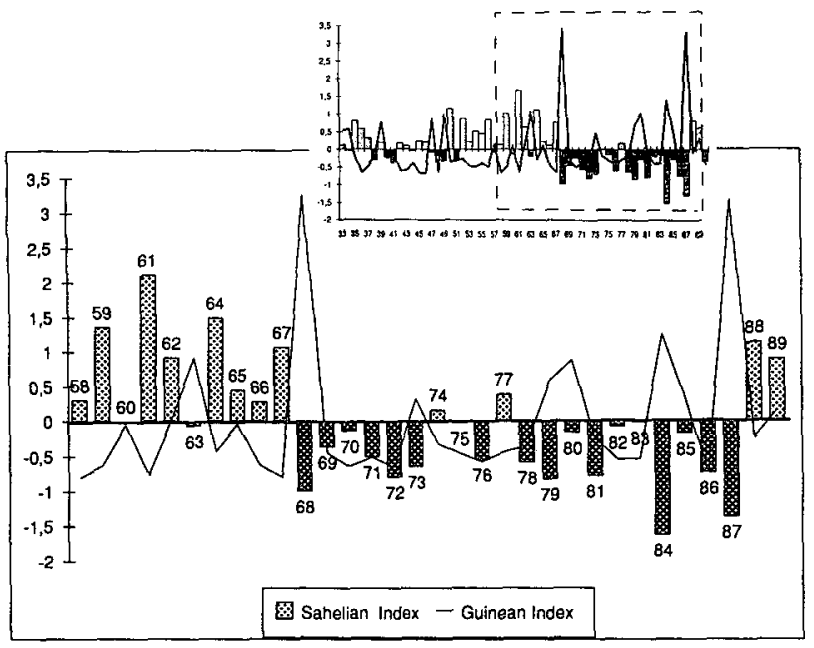

FIG. 1. Standardized time series of the two August rainfall indexes (central Sahelian rainfall index, solid lines; Guinean rainfall index, vertical bars) for the periods 1933-1990 and 1958-1989.

than GI: an anomalously wet period (1958-1967) is followed by an anomalously dry one (1968-1987) before a slight recovery in 1988-1989. Much of the variance of GI is concentrated during the two wettest occurrences $(1968,1987)$, which, along with 1984 , are also the driest August episodes in the Sahel for the period 1933-1989. The four basic rainfall types are not equally documented. One can consider that a rainfall type is clearly defined when the absolute value of standardized anomalies of rainfall indexes are greater than 0.25 . Since the period $1958-1989$ is rather dry regarding the longer term mean 1933-1989, only three out of four rainfall types can be clearly defined (the --, -+ , and +- patterns). The -- rainfall anomaly pattern will then refer to six months of August (1971, 1972, 1976, 1978, 1981, and 1986); - + refers to four months of August (1968, 1979, 1984, and 1987); and +- refers to four months of August (1959, 1961, 1964, and 1967). The ++ pattern is not present on the period and thus will not be investigated hereafter.

\section{b. Wind fields in August}

According to the limitations of the analyzed upper-air data (Oort 1983, p. 74), most of the results will then be displayed on meridional cross sections along the Greenwich meridian from $10^{\circ} \mathrm{S}$ to $30^{\circ} \mathrm{N}$ in the $1000-50-\mathrm{hPa}$ layer (Fig. 2). The cross section of zonal components shows the three dominant flows: the TEJ (150-200 hPa) with maxima of $16 \mathrm{~m} \mathrm{~s}^{-1}$ at $200 \mathrm{hPa}$ above $10^{\circ}-5^{\circ} \mathrm{N}$, the AEJ (450-700 hPa) with maxima of $8 \mathrm{~m} \mathrm{~s}^{-1}$ at 600 hPa above $15^{\circ} \mathrm{N}$, and the westerly component of the monsoon flow with maxima greater than $2 \mathrm{~m} \mathrm{~s}^{-1}$. The AEJ appears limited to the Sudano-Sahelian belt, but the TEJ and the westerly component of the monsoon flow concern also Guinean latitudes. In the upper tro- posphere, positive values on northern and southern borders indicate the presence of subtropical westerly jets. The cross section of meridional components shows smaller values. However, the presence of southerlies in lower layers south of $18^{\circ} \mathrm{N}$ and of northerlies above 400 $\mathrm{hPa}$ south of $10^{\circ} \mathrm{N}$ shows that the southern Hadley cell dominates. Above $25^{\circ} \mathrm{N}$, the presence of both midtropospheric northerlies greater than $2 \mathrm{~m} \mathrm{~s}^{-1}$ at $500 \mathrm{hPa}$ and southerlies greater than $1 \mathrm{~m} \mathrm{~s}^{-1}$ in the $100-200 \mathrm{hPa}$ layer depicts the northern Hadley circulation.

The West African monsoon dynamics is analyzed by using the "teleconnectivity" method (Wallace and Gutzler 1981). Correlation coefficients are computed on zonal $(U)$ and meridional $(V)$ wind components along the vertical. According to $U$ and $V$ mean values, the strongest negative correlations between lower and upper levels depict the dynamics of east-west circulations and Hadley-type cells. The example displayed in Table 1 for the $U$ components shows significant negative values between the $950-500$ and $300-100 \mathrm{hPa}$ layers. The strongest coefficient, recorded between the 200 and $850 \mathrm{hPa}$ levels $(r=-0.73)$, confirms the relationship between the TEJ and the upper limit of the monsoon layer (Fig. 2). When linear trends are removed, absolute values of these coefficients diminish by about $10 \%$ but remain significant. This agrees with the existence of an east-west circulation whose upper branch is associated with the TEJ and lower branch with the westerly component of the monsoon flow (Fontaine and Janicot 1992). The vertical distribution of correlation coefficients between meridional components is different since significant negative values concern mainly the lowest (950-900 hPa) and highest (50-200 hPa) levels of the troposphere (not shown). However, values are weaker than those obtained with $U$ components, and only two areas exhibit coefficients lower than -0.5 , namely, east of Lake Chad and off Mauritania.
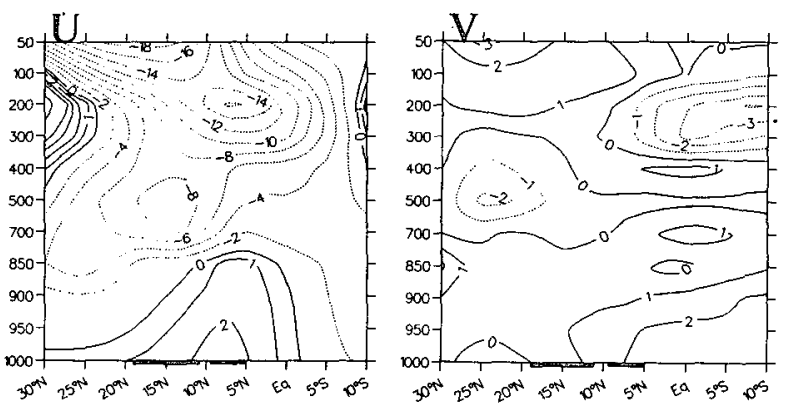

FIG. 2. Mean meridional cross sections along the Greenwich meridian of August (1958-1989) $U$ component (left, positive eastward with a $2 \mathrm{~m} \mathrm{~s}^{-1}$ step) and $V$ component (right, positive northward with a $1 \mathrm{~m} \mathrm{~s}^{-1}$ step). Pressure levels in $\mathrm{hPa}$ and latitudes are respectively indicated on vertical and horizontal axes. Latitudinal extensions of the Sahelian and of the Guinean areas are indicated. The 11 available pressure levels are equally spaced on the vertical axis to limit the representation of the stratospheric layer (above $100 \mathrm{hPa}$ ) and to detail some significant features in the low and midtroposphere. 


\section{c. Connections between the Sahelian rainfall index and the wind field}

Meridional cross sections of correlation coefficients along the Greenwich meridian are shown (Fig. 3) between CSI and $U$ components, and CSI and $V$ components. Positive coefficients indicate that stronger (weaker) than usual rainfall anomalies in the central Sahel are encountered with more westerly or southerly (easterly or northerly) wind components. Reduced Sahelian rainfall amounts are connected with 1) a weaker southerly component of the monsoon flow between $10^{\circ} \mathrm{S}$ and the equator where this is mostly a meridional flow and 2) a reduced and lowered westerly component between $5^{\circ}$ and $15^{\circ} \mathrm{N}$ where this is mostly a zonal flow. In the midtroposphere, the AEJ does not show any significant variation of its core speed, but we can notice, in its southern edge, an increase and a southward and downward extension of its easterly component. Under its northern edge, a synchronous but not significant decrease of its easterly component appears at $20^{\circ} \mathrm{N}, 850 \mathrm{hPa}$. High-tropospheric dynamics is quite different since the TEJ core speed weakens and shows a slight southward displacement of its northern border. In fact, this decrease concerns a large part of the upper troposphere through the southern Hadleytype circulation associated with the deep convection inside the ITCZ. However, the highest level $(50 \mathrm{hPa})$ is no longer submitted to this wind modulation. Here again, significant results were obtained after removing all linear trends in the series.

Two areas of strong correlation gradients exist below $100 \mathrm{hPa}$ : a vertical one located at $10^{\circ}-15^{\circ} \mathrm{N}$ in the 400-200 $\mathrm{hPa}$ layer and a quasi-horizontal one between $15^{\circ} \mathrm{N}$ and $10^{\circ} \mathrm{S}$ in the $500-900 \mathrm{hPa}$ layer. This delineates two main coherent domains in the wind field in relation to the Sahelian rainfall variability: the 200 $\mathrm{hPa}$ easterly flow associated with monsoon dynamics and the southern edge of AEJ. The AEJ, closely linked to the monsoon flow inside the "meteorological equator" (Dhonneur 1974), is then mostly disturbed by latitudinal and vertical displacements of its southern
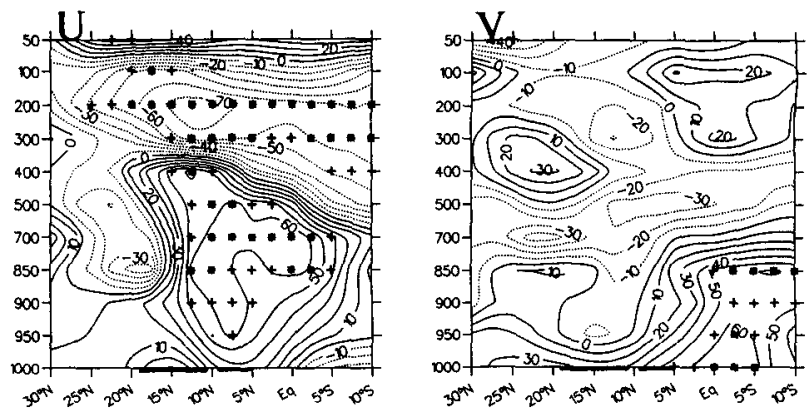

FIG. 3. Meridional cross sections along the Greenwich meridian of correlation coefficients between CSI and $U$ component (left) and CSI and $V$ (right) component in August (1958-1989). "Point," "plus," and "star" characters indicate correlations significant at the $10 \%, 5 \%$, and $1 \%$ levels after taking into account the space and time autocorrelation. Latitudinal extensions of the Sahelian and Guinean areas are indicated.

edge. As these connections are most effective under $700 \mathrm{hPa}$, we suggest that the AEJ dynamics is controlled by the monsoon flow and by the rainfall pattern through the partition between sensible and latent heat fluxes. When the West African monsoon is weak, moisture supply is also weak and Sahelian rainfall is lower than average. Consequently, latent heat flux (through evaporation processes) decreases and heat transfer is essentially due to sensible heat over the Sahelian belt, which results in warmer lower-layer temperatures in the northern part. This leads to an enhancement of the mean meridional West African temperature gradient in the lower layers and thus of the easterly component of the thermal wind. Therefore, the combination of a latitudinal retreat of the westerly component of the monsoon flow and of an increase of the easterly component of the thermal wind implies a southward and downward extension of the AEJ core.

From the above results a West African monsoon index (WAMI) is defined in August at $7.5^{\circ} \mathrm{N}, 0^{\circ}$ as follows:

$$
\mathrm{WAMI}=M 900-U 200,
$$

where $M 900$ is the standardized anomaly of the wind

TABLE 1. Correlation coefficients between standardized anomalies of zonal wind components at $5^{\circ} \mathrm{N}, 0^{\circ}$ in August from 1000 to $50 \mathrm{hPa}$ for the period 1958-1989. Significant values at the 5\% level are italic.

\begin{tabular}{|c|c|c|c|c|c|c|c|c|c|c|c|}
\hline Level $\mathrm{hPa}$ & 1000 & 950 & 900 & 850 & 700 & 500 & 400 & 300 & 200 & 100 & 50 \\
\hline 50 & & & & & & & & & & & 100 \\
\hline 100 & & & & & & & & & & 100 & 20 \\
\hline 200 & & & & & & & & & 100 & 18 & -26 \\
\hline 300 & & & & & & & & 100 & 81 & 06 & -28 \\
\hline 400 & & & & & & & 100 & 37 & 23 & -12 & -02 \\
\hline 500 & & & & & & 100 & 21 & -36 & -56 & -24 & 09 \\
\hline 700 & & & & & 100 & 61 & 17 & -60 & -66 & -38 & 22 \\
\hline 850 & & & & 100 & 77 & 45 & -16 & -64 & -73 & -33 & 10 \\
\hline 900 & & & 100 & 59 & 56 & 56 & -12 & -40 & -60 & -37 & 08 \\
\hline 950 & & 100 & 92 & 37 & 42 & 46 & -03 & -32 & -50 & -32 & 10 \\
\hline 1000 & 100 & 91 & 75 & 25 & 31 & 36 & 02 & -33 & -45 & -24 & 13 \\
\hline
\end{tabular}




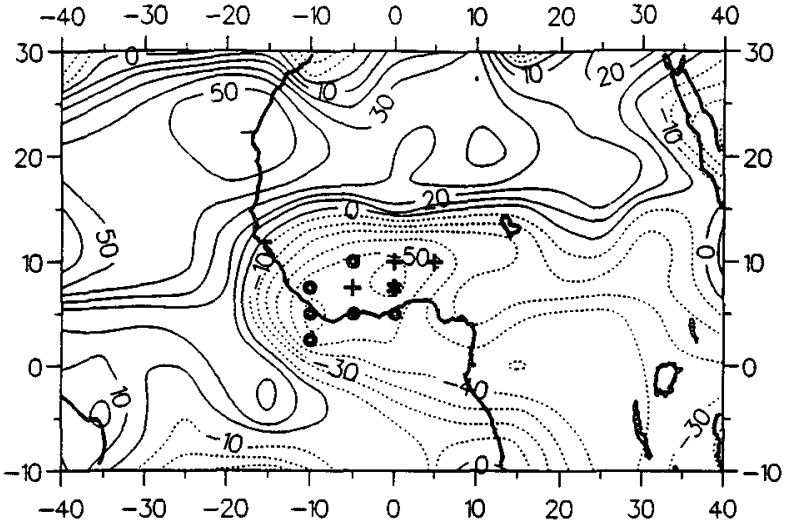

FIG. 4. Map of correlation coefficients $(\times 100)$ between the wind modulus at $900 \mathrm{hPa}$ and the zonal components of the wind at 200 hPa in August (1958-1989). "Circle," "plus," and "star" characters indicate correlations significant at the $10 \%, 5 \%$, and $1 \%$ levels after taking into account the space and time autocorrelations.

modulus at $900 \mathrm{hPa}$, and $U 200$ is the standardized anomaly of the zonal component of the wind at 200 $\mathrm{hPa}$. The grid point $7.5^{\circ} \mathrm{N}, 0^{\circ}$ is the location of the highest negative correlations $(-0.67$ and -0.62 without linear trends) between $M 900$ and U200 (Fig. 4). WAMI is then standardized for the period 1958-1989: a high (low) value represents an enhanced (a reduced) southwesterly monsoon flux and/or a stronger (weaker) TEJ. Correlations between WAMI and the two rainfall indexes are different: weakly negative with GI ( $r=-0.33)$ but greatly positive with CSI $(r=0.73$ and 0.66 without linear trends). Note that WAMI, defined without any a priori relation to the rainfall field, is strongly linked to rainfall anomalies in the central Sahel (Fig. 5).

\section{d. Connections between the rainfall anomaly patterns and the wind field}

\section{1) COMPOSITE CROSS SECTIONS ALONG THE GREENWICH MERIDIAN}

Differences between 1 ) the mean profiles of the wind field for the three composited rainfall patterns (--, -+ , and +- ) and 2 ) the mean profiles of the respective remaining periods are presented in the form of meridional cross sections (Fig. 6) of $U$ and $V$ components along $0^{\circ}$.

The -- cross sections (Fig. 6a) show significant positive values with $U$ components above $500 \mathrm{hPa}$ south of $3^{\circ} \mathrm{S}$, which is coherent with a less southward extension of upper easterlies associated with the TEJ and/or a northward extension of the upper southern westerlies (Janicot 1992b). Negative (positive) values refering to $V$ components at $300 \mathrm{hPa}$ north of $20^{\circ} \mathrm{N}$ $\left(200 \mathrm{hPa}\right.$ near $\left.10^{\circ} \mathrm{N}\right)$ suggest a decrease of upper southerlies (northerlies) associated with the upper portion of the northern (southern) Hadley cell. This is

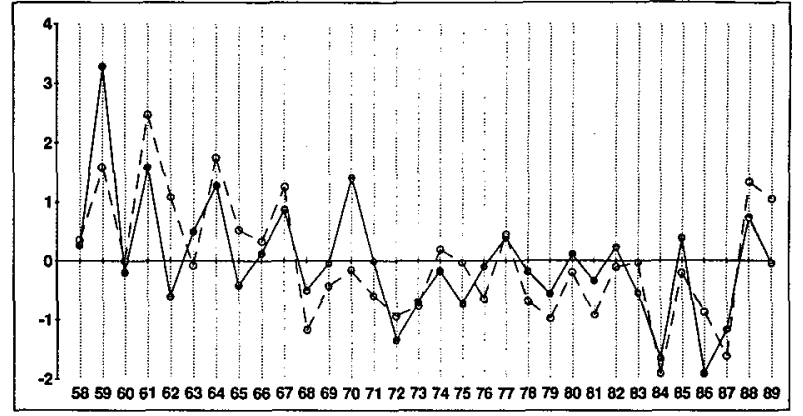

FIG. 5. Standardized time series in August (1958-1989) of the West African monsoon index (solid line) and the central Sahel rainfall index (dashed line).
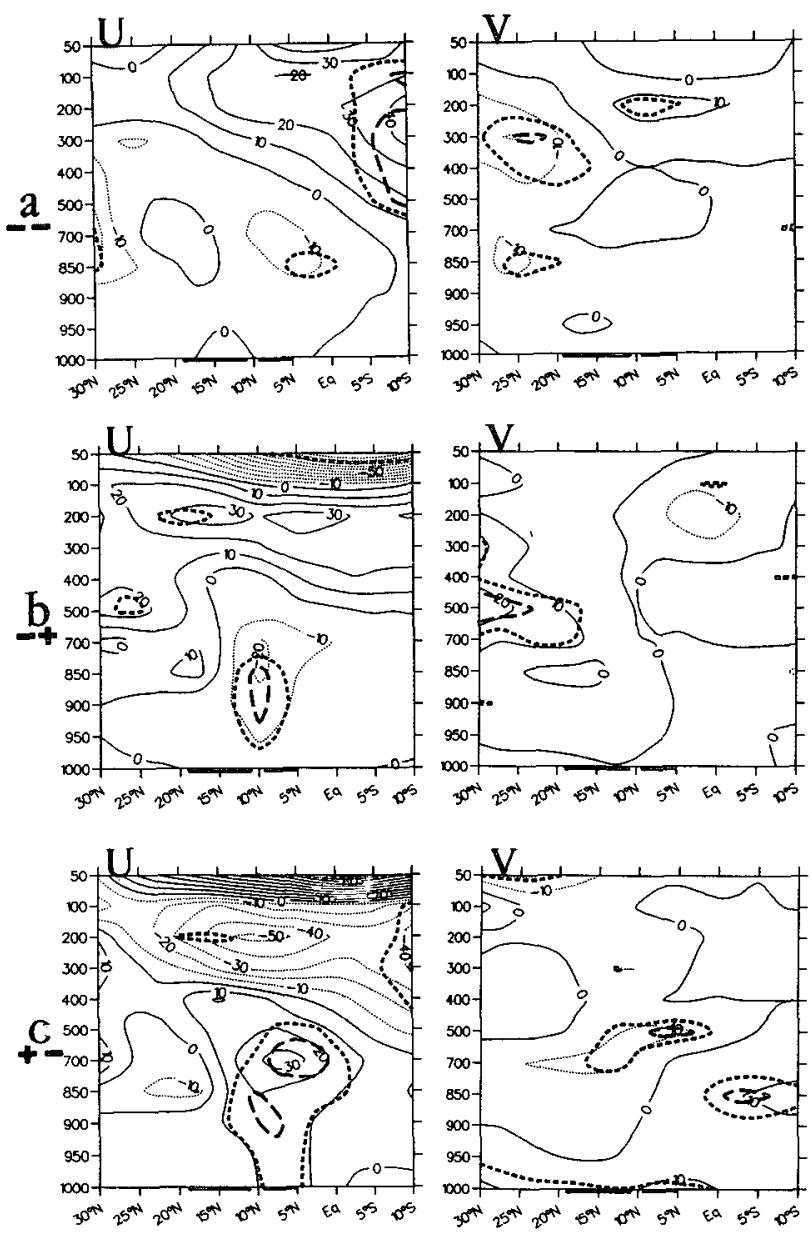

FIG. 6. Meridional cross section of $U$ (left) and $V$ (right) differences (in tenths of $\mathrm{m} \mathrm{s}^{-1}$ ) between each composite period and all the remaining months of August. Results refer to the $--(a),-+(b)$, and +- (c) rainfall anomaly patterns. Dotted, dashed, and solid superimposed lines indicate significant values at the $10 \%, 5 \%$, and $1 \%$ levels after taking into account the space and time autocorrelations. Latitudinal extensions of the Sahelian and Guinean areas are indicated. 
coherent with the weakening of the ITCZ convection in all of the West African troposphere under $300 \mathrm{hPa}$. The nonsignificance in AEJ variations and the TEJ decrease in rainfall types - - were also suggested in Janicot (1992b).

During -+ occurrences (Fig. 6b) an easterly wind anomaly in the equatorial zonal circulation above 100 $\mathrm{hPa}$ will enhance (reduce) the easterly (westerly) phase of the quasi-biennal oscillation (QBO). In fact, the east phase of the QBO is verified during each occurrence of the four months of August that define the - + composite period $(1968,1979,1984,1987)$ since the $U$ component at $50 \mathrm{hPa}$ and above the equator is always negative. The enhancement of anomalous easterlies south and under the main axis of the AEJ has been previously shown in Fig. 3. Note also the reduction of about $1 \mathrm{~m} \mathrm{~s}^{-1}$ in the monsoon flow above $950 \mathrm{hPa}$, the strengthening of about $2 \mathrm{~m} \mathrm{~s}^{-1}$ in the easterlies under $700 \mathrm{hPa}$, the decrease of $-3 \mathrm{~m} \mathrm{~s}^{-1}$ in the TEJ easterlies at $200 \mathrm{hPa}$, and the significant southerly anomaly in the midtroposphere north of $18^{\circ} \mathrm{N}$, consistent with a weaker northern Hadley cell (Fig. 6b). This tends to create an abnormal subsidence under $500 \mathrm{hPa}$ and above the Sahelian belt, suggesting a southward location of the main ascending branch of the monsoon cell. No coherent signal is found in the monsoon flow. The AEJ enhancement along with the nonsignificant differences in the TEJ wind field were suggested in Janicot ( $1992 b$ ).

During +- occurrences (Fig. 6c) a westerly wind anomaly in the equatorial zonal circulation above 100 $\mathrm{hPa}$ will enhance (reduce) the westerly (easterly) phase of the QBO. Here again, the west phase of the QBO is verified during each occurrence of the four months of August that define the +- composite period (1959, $1961,1964,1967)$, the $U$ component at $50 \mathrm{hPa}$ and above the equator being always positive. Negative values in the 400-100 hPa layer south of $5^{\circ} \mathrm{S}$ are coherent with a southward extension of easterlies associated with the TEJ and/or with a decreasing speed in northern borders of the subtropical westerly jet in the Southern Hemisphere. The presence of significant positive values in the low and midtroposphere between the equator and $15^{\circ} \mathrm{N}$ is consistent with both 1 ) a decrease of $U$ components (increasing easterlies) extending on the southern edge of the AEJ and 2) an increase of $U$ components in the upper levels of the monsoon flow. Composite differences computed on $V$ components depict an enhancement of southerlies in the monsoon flow (Fig. 6c). Positive values at $850 \mathrm{hPa}$ south of the equator and negative ones in the midlayer between the equator and $15^{\circ} \mathrm{N}$ show that southerlies at $5^{\circ} \mathrm{S}$ and northerlies above West Africa both appear stronger than average. This is coherent with a reinforcement of the subsidence in the lower levels above $5^{\circ} \mathrm{N}-0^{\circ}$, suggesting an accentuated little dry season over the Gulf of Guinea.

\section{2) RAINFALL ANOMALY PATTERNS AND RELATED WIND INDEXES}

Above results suggest the ability of very simple wind indexes to document the three rainfall-type occurrences $(-+,+-$, and --) over the 32 months of August 1958-1989. They allow us to focus on the most prominent signals in the monthly wind field associated with the rainfall anomaly patterns.

From correlations computed between CSI and the wind field, an index is defined by the difference between standardized values of $U 850$ at the location $10^{\circ} \mathrm{N}, 0^{\circ}$ and $U 200$ at $5^{\circ} \mathrm{N}, 0^{\circ}$ (called hereafter $U 850-U 200$ ) to take into account the east-west circulation. Correlation between this index and CSI is strong $(r=+0.77)$ and remains significant when linear trends are removed $(r=+0.65$ ). Time series of $U 850-U 200$ (Fig. 7a) separates the two contrasted rainfall patterns $(-+$ and $+-)$. The -+ occurrences are associated with the highest negative values (i.e., a weak east-west circulation), while +- patterns are synchronous with the highest positive values (i.e., a strong east-west circulation). Note also that except in 1969 and 1971, the - - patterns, as the - + ones, correspond to a negative value of the index. The difference between standardized $U$ components at $850 \mathrm{hPa}$ for $10^{\circ}$ and $20^{\circ} \mathrm{N}$ (called hereafter $U 10 \mathrm{~N}-U 20 \mathrm{~N}$ ) is also efficient to differentiate the two contrasted rainfall types (Fig. $7 \mathrm{~b}$ ) since correlation coefficients between $U 10 \mathrm{~N}-U 20 \mathrm{~N}$ and the two rainfall indexes are opposite: they are of $+0.72(+0.59$
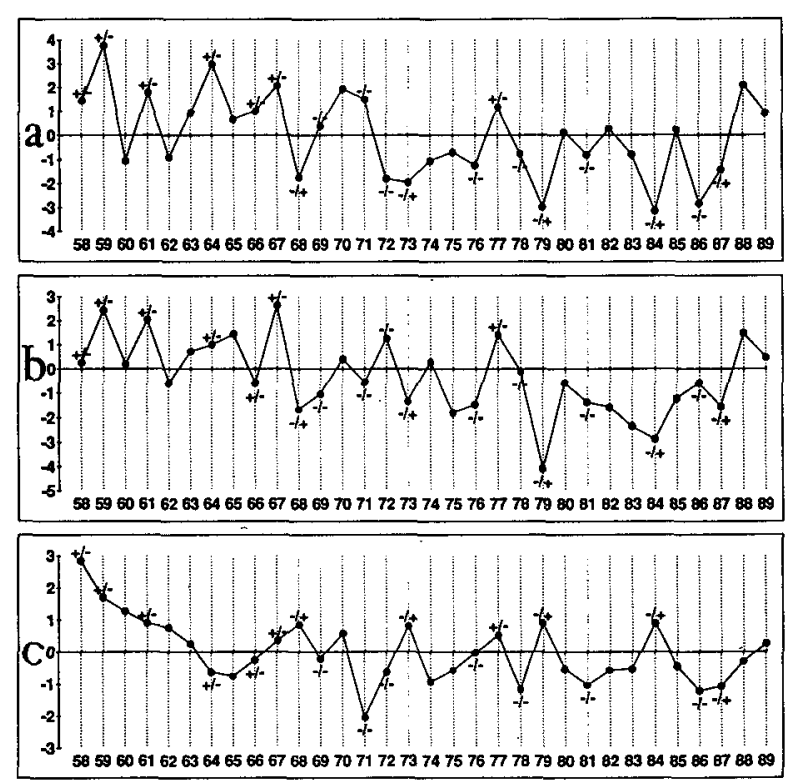

FIG. 7. Time series of the difference between standardized values of (a) the $U$ component at $850 \mathrm{hPa}\left(10^{\circ} \mathrm{N}, 0^{\circ}\right)$ and at $200 \mathrm{hPa}\left(5^{\circ} \mathrm{N}\right.$, $\left.0^{\circ}\right)$, (b) the $U$ components at $850 \mathrm{hPa}\left(10^{\circ} \mathrm{N}, 0^{\circ}\right.$ and $\left.20^{\circ} \mathrm{N}, 0^{\circ}\right)$, and (c) the $V$ components $\left(22.5^{\circ} \mathrm{N}, 0^{\circ}-300 \mathrm{hPa}\right.$ and $7.5^{\circ} \mathrm{N}, 0^{\circ}-200$ hPa) in August (1958-1989). The three rainfall types occurrences $(--,-+$, and +-$)$ are superimposed. 
after removing linear trends) with CSI and of -0.39 $(-0.33)$ with GI. The reason is that $U 10 \mathrm{~N}-U 20 \mathrm{~N}$ reflects north-south displacements of the zonal mean circulation above the boundary layer. $U 10 \mathrm{~N}-U 20 \mathrm{~N}$ well separates the +- and -+ occurrences, while the - - patterns marked by intermediate values are not well discriminated (Fig. 7b).

Results relative to -- occurrences (Fig. 6a) have shown a sign reversal in $V$ components in the high tropospheric levels that does not appear during -+ and +- ones (Figs. $6 b, c$ ). The velocity difference between standardized $V$ components at $22.5^{\circ} \mathrm{N}, 300$ $\mathrm{hPa}$ and $7.5^{\circ} \mathrm{N}, 200 \mathrm{hPa}$ can then be computed. Its negative (positive) values in the upper-troposphere document anomalies of confluence (diffluence) in the Hadley circulation associated with regional-scale downward (upward) anomaly motion. Figure 7c shows that - - occurrences correspond to negative values of this index $(1969,1971,1972,1978,1981,1986)$, while positive values are associated with either -+ (1968, $1973,1979,1984)$ or $+-(1961,1967,1977)$ rainfall anomaly patterns. An enhancement of the upper confluence in the Hadley circulation (and a weakening of upward motions) may be viewed as a necessary atmospheric forcing for large-scale deficits over West Africa.

\section{Conclusions}

This diagnostic investigation of relationships between rainfall anomaly patterns and wind field above West Africa has confirmed earlier results. By using a longer dataset and considering both Sahelian and Guinean rainfall anomalies, it has also provided new features. In particular, deficient rainfall occurrences in the central Sahel are synchronous of decreases of the TEJ and of the southwesterly monsoon flow (Newell and Kidson 1984; Fontaine and Janicot 1992). However, the presence of correlations of opposite signs north and south of $15^{\circ} \mathrm{N}$ between the $900-500 \mathrm{hPa}$ zonal wind and the central Sahel rainfall is a new result. This appears to be coherent with a northward (southward) shift of the easterly circulation at $850 \mathrm{hPa}$ during wet (dry) occurrences in the central Sahel. Correlation coefficients computed on zonal and meridional wind components have shown the existence of significant vertical relationships between lower and higher levels of the troposphere. This complements results of Fontaine and Janicot (1992) and has enabled us to define a West African monsoon index of regional extension, well connected with the central Sahel rainfall and useful to diagnose the West African monsoon cell circulation.

More interesting results have been obtained when the Sahelian and Guinean rainfall anomalies are both considered. A significant part of the interannual variance of West African rainfall anomaly fields is due to the opposite evolution between central Sahelian and Guinean rainfall indexes, which appears reinforced in the recent period (1958-1989). Consequently, two contrasted rainfall patterns, delineated - + when Sahelian droughts are associated with Guinean floods and +- for the opposite, have been produced. Results have shown that a stronger (weaker) wind velocity on the southern borders of the AEJ corresponds mainly to à $-+(+-)$ rainfall pattern, since this pattern tends to enhance (to reduce) southward meridional temperature gradients in the lower layers. Main signals in +- rainfall occurrences reflect both a reduction of the midtropospheric easterlies and an enhancement in the upper levels of the westerly component of the monsoon flow. On the contrary, during -+ occurrences they rather indicate a reduction of the zonal velocity in the upper levels of the monsoon flow. A third rainfall pattern delineated --, when Sahelian droughts are concomitant to Guinean droughts, has not shown any significant speed variation in AEJ, consistent with suggestions in Janicot (1992b).

Lamb (1983) investigated water vapor variations over West Africa for individual wet (1967, 1969, 1975) and dry $(1968,1971,1972)$ Sahelian rainy seasons. He showed that at $13^{\circ} \mathrm{N}$ the better developed nondrought southwesterly flows tended to be thicker than those characteristic of most drought cases, which is consistent with the results presented here. Lamb (1983) also noticed that along $5^{\circ} \mathrm{N}$, thickness variability of the monsoon layer was very high and that the monsoon-layer depth during the nondrought years did not always exceed that for drought cases. Figure 1 shows that dry Sahelian months of August 1968 and 1972 are defined by a different West African rainfall anomaly pattern (Guinean flood in 1968 and Guinean drought in 1972). In the same way, the months of August 1969 and 1972 both correspond to a Guinean drought. This could explain the noncorrespondence between Sahel rainfall variability and monsoon layer depth along the Guinean coast and confirm the idea of considering West African rainfall anomaly patterns rather than Sahel rainfall anomalies alone. This point was also developed in Janicot (1992b). In contrast, our Fig. 6 has not depicted any significant variation in the monsoon wind field along $5^{\circ} \mathrm{N}$ for -+ occurrences relative to -- occurrences. This could indicate the better accuracy of the vertically integrated monsoon layer water vapor used by Lamb (1983) to characterize variability of monsoon dynamics.

An easterly (westerly) phase of the QBO and hence of wind anomaly in the equatorial stratosphere appears also significant in each $-+(+-)$ occurrence documented in the period 1958-1989. Gray et al. (1992) suggested that QBO could alter the distribution of deep convection in many places in the Tropics. The hypothesis of a QBO forcing on West African rainfall merits further investigation. It seems also that QBO could have a small but significant contribution to seasonal forecasts of Sahelian rainy season (Landsea et al. 1993). 
These findings also allowed us to define some very simple wind indexes for discriminating the three rainfall types referenced on the available period. The two contrasted rainfall types $(-+$ and +-$)$ are well documented when zonal wind components are considered: a zonal cell circulation signal or a simple signal of the latitudinal location of both the westerly component of the monsoon flow and the AEJ are useful to diagnose types -+ and +- . By contrast, the occurrences of types - - are well documented with a signal taking into account confluence variability in the meridional wind field due to the Hadley cell in the high troposphere and hence the enhancement of subsidence anomalies over the whole of West Africa (Janicot 1992b). These three monthly indexes can be considered as the most prominent regional signals in the wind field associated with interannual variability of the August rainfall anomaly fields over West Africa during the period 1958-1989.

Acknowledgments. The authors are very thankful to NCAR, CILSS, AGRHYMET, and the numerous African administrations for providing the rainfall data, and to Abraham $\mathrm{H}$. Oort for providing the "GFDL Atmospheric Circulation Tape Library 1958-1989." The authors are also grateful to Pierre Camberlin for reading the manuscript, to Dr. P. J. Lamb and the anonymous reviewers for their comments, which greatly improved the manuscript, and to Chris Landsea for his encouragements and his thought-provoking comments.

\section{REFERENCES}

Cadet, D. L., and N. Nnoli, 1987: Water vapour transport over West Africa and the Atlantic Ocean during summer 1979. Quart. J. Roy. Meteor. Soc., 113, 581-602.

Dennett, M. D., J. Elston, and J. A. Rogers, 1985: A reappraisal of rainfall trends in the Sahel. J. Climatol., 5, 353-361.

Der Megreditchian, G., 1979: L'optimisation des réseaux d'observations des champs météorologiques. La Météorologie, VI, 17, $51-66$.

Dhonneur, G., 1974: Nouvelle approche des réalités météorologiques de l'Afrique occidentale et centrale. Publications ASECNA, Dakar (Sénégal), 385 pp and 472 pp.

Folland, C. K., T. N. Palmer, and D. E. Parker, 1986: Sahel rainfall and worldwide sea temperature 1901-1985. Nature, 320, 602607.

Fontaine, B., and S. Janicot, 1992: Wind field coherence and its variations over West Africa. J. Climate, 5, 512-524.

Gray, W. M., J. D. Sheaffer, and J. A. Knaff, 1992: Influence of the stratospheric QBO on ENSO variability. J. Meteor. Soc. Japan, 71, 975-995.

Hastenrath, S., and P. J. Lamb, 1977: Some aspects of circulation and climate over the eastern equatorial Atlantic. Mon. Wea. Rev., 105, 1019-1023.

Janicot, S., 1992a: Spatio-temporal variability of West African rainfall. Part I: Regionalizations and typings. J. Climate, 5, 489-497.

-, 1992b: Spatio-temporal variability of West African rainfall. Part II: Associated surface and airmass characteristics. J. Climate, 5, 499-511.
Janowiak, J. E., 1988: An Investigation of interannual rainfall variability in Africa. $J$. Climate, 1, 240-255.

Katz, R. W., and M. H. Glantz, 1986: Anatomy of rainfall index. Mon. Wea. Rev., 114, 764-771.

Kidson, J. W., 1977: African rainfall and its relation to the upper air circulation. Quart. J. Roy. Meteor. Soc., 103, 441-456.

Koteswaram, P., 1958: The easterly jet stream in the tropics. Tellus, $10,43-57$

Lamb, P. J., 1983: West African water vapor variations between recent contrasting Subsaharan rainy seasons. Tellus, Ser. A, 35, 198212.

Landsea, C. W., W. M. Gray, P. W. Mielke, and K. J. Berry, 1993: Predictability of seasonal Sahelian rainfall by 1 December of the previous year and 1 June of the current year. Preprints, 20th Conf. on Hurricanes and Tropical Meteorology, San Antonio, TX, Amer. Meteor. Soc., 473-476.

Livezey, R. E., and W. Y. Chen, 1983: Statistical field significance and its determination by Monte Carlo techniques. Mon. Wea. Rev., 111, 46-59.

Monteny, B. A., 1985: Importance of the tropical rain forest as an atmospheric moisture source. Proc., ISLSCP Conf., Roma, Italy, ISLSCP, 221-225.

Moron, V., 1992: Variabilité spatio-temporelle des précipitations en Afrique Sahélienne et Guinéenne (1933-1990). La Météorologie, 43/44, 24-30.

- 1994 : Guinean and Sahelian rainfall anomaly indices at annual and monthly time scales (1933-1990). Int. J. Climatol., 14, 325-341.

Newell, R. E., and J. E. Kidson, 1984: African mean wind changes between Sahelian wet and dry periods. J. Climatol., 4, 27-33.

Nicholson, S. E., 1981: Rainfall and atmospheric circulation during drought periods and wetter years in West Africa. Mon.Wea. Rev., 109, 2191-2208.

- 1986: The spatial coherence of African rainfall anomalies: Interhemispheric teleconnections. J. Climate Appl. Meteor., 25, 1365-1381.

-, and I. M. Palao, 1993: A Re-evaluation of rainfall variability in the Sahel. Part I: Characteristics of rainfall fluctuations. Int. J. Climatol., 13, 371-390.

Oort, A. H., 1978: Adequacy of the rawinsonde network for the global circulation studies tested through numerical model output. Mon. Wea. Rev., 106, 174-195.

- 1983: Global atmospheric circulation statistics: 1958-73. NOAA Prof. Paper, 14, 179 pp.

- , and H. Liu, 1993: Upper-air temperature trends over the globe, 1958-1989. J. Climate, 6, 292-307.

Reed, R. J., D. C. Norquist, and E. E. Recker, 1977: The structure and properties of African wave disturbances as observed during phase III of GATE. Mon. Wea. Rev., 105, 317-333.

Rennick, M. A., 1976: The generation of African waves. J. Atmos. Sci., 33, 1955-1969.

Riehl, H., 1979: Climate and Weather in the Tropics. Academic Press, $611 \mathrm{pp}$.

Sneyers, R., 1975: Sur l'analyse statistique des séries d'observations. Geneve, 415, 218 pp.

Song, J. L. and W. H. Frank, 1983: Relationship between deep convection and large-scale processes during GATE. Mon. Wea. Rev., 111, 2145-2160.

Thiebaux, H. J. and F. W. Zwiers, 1984: The interpretation and estimation of effective sample size. J. Climate Appl. Meteor., $23,800-811$.

Wallace, J. M., and D. S. Gutzler, 1981: Teleconnections in the geopotentiel height field during the northern winter. Mon. Wea. Rev., 109, 784-812. 